\title{
Impact of Television Advertisement on Undergraduate Students' Purchase Decision on Indomie Noodles
}

\author{
Ikechukwu, Favour $\mathrm{C}^{1} \&$ Agu, Godswill $\mathrm{Agu}^{1}$ \\ ${ }^{1}$ Department of Marketing, Abia State University, Uturu, Nigeria \\ Correspondence: Agu, Godswill Agu, Department of Marketing, Abia State University, Uturu, Nigeria.
}

Received: November 16, 2018; Accepted: December 3, 2018; Published: December 10, 2018

\begin{abstract}
This study surveys undergraduate students' views on the effect of television advertisement on their purchase of indomie noodles. 392 respondents, drawn from the Business Administration unit of Abia State University were studied. The structured questionnaire was administered on the select respondents. The SPSS version 20 students t-test was used to test stated hypotheses. Finding disclosed that television advertising has a significant influence on students' preference, patronage and repeat purchase of indomie noodles. The study recommends that Advertising messages should be clear, credible and precise so that the target market will not give different meanings to it and that noodles marketers should see television advertising as a long-term investment into the life of products and not be discouraged by the early, immediate low returns of advertisements.
\end{abstract}

Keywords: television advertisement, purchase decision, indomie noodle, undergraduate students

\section{Introduction}

The dynamism and complexities in the world of business today have led business organizations into a state of competition as to making better decisions. Emphases on an effective communication tool that will guide consumers buying decisions are being adjusted to suit both parties and so strategies are being put into place to win consumers' loyalty. According to Okpara, (2012) a good product requires the creation of awareness and conviction for purchase by customers. Promotion being the major tool of communication in the world of business has being defined by Okpara, Anyanwu and Inyanga (1999) as the way and means of packaging and disseminating a potentially commercial message by a seller to a buyer in order to elicit the intended response from the latter. This bridges the gap of ignorance and creates deeper awareness in potential buyers. When customers are not well informed about the existence of a product, it depletes sales volume compared to when it is effectively publicized, and so advertising plays a major role to inform, persuade and remind customers about the existence of a product, thus stimulates demand.

Effective advertising is made possible through a medium (Okpara \& Agu, 2016). These media range from the print to the electronic or broadcast media, including the Information Communication Technologies (ICTs) (Awa \& Kalu, 2016). The television is an electronic media used as a medium of advertising. Television Advertising is a span of television programming produced and paid for by the organization that conveys a message for promoting a wide variety of goods, services and ideas (Stephen, 2010). This seeks to influence the consumption of products. In Nigeria, TV advertising remains a major medium in marketing instant noodles, especially to children.

This study tends to evaluate the impact of television advertising on Indomie noodles consumption behaviour of university students.

\subsection{The Problem}

As important as television advertising is in the creation of awareness about the existence of a product or service, it appears most firms still do not understand its strength as a patronage driver. Television advertising as a medium of communication has gained importance in the marketing of products. It has become a prime medium with its attractive features of sight, colour and motion.

Television advertising is costly with often an uncertain effect and sometimes. In some cases, it may take a while before it makes any noticeable impact on sales. Yet, insightful firms view advertising expenses as investment.

Observation has shown that many undergraduate university students who live on campuses consume noodles regularly. But there is no known television advertisement that targets this set of consumers. Noodles marketers believe that the general television ads that targets children and working class consumers can serve this group. 
This study is poised to ascertain the impact of television advertising on noodles consumption among students of Abia State University.

\subsection{Objectives of the Study}

This study is guided by the following objectives.

1. To investigate the extent to which television advertising influences the patronage of indomie noodles.

2. To determine whether television advertising increases consumers' preference of indomie brand of noodles.

3. To ascertain whether television advertising creates a repeat purchase of indomie noodles.

\section{Review of Related Literature}

\subsection{Television Advertising}

A television advertising or commercial is a form of advertising in which goods, such as indomie instant noodles, services etc are promoted through the medium of television. This type of advertising possesses certain characteristics of which, the use of songs, jingles and humour, catchy jingles and phrases (indomie like no other)etc to generate sustained appeal which may remain long after the advertising campaign. Advertising that made use of television as a medium of communication is referred to as Television Advertising.

Anyawu $(2003 ; 183)$, grouped television advertising into four distinct groups. He noted that television commercial shares the same denominator with both radio and cinema advertisement because the adverts in both, exist in time and not in space. Media buyers buy airtime in the case of broadcast media and space in case of print media. Anyawu(2003) stressed on the following groups:

\section{Qualities of good TV commercials;}

i. Words and illustration that will arrest viewers' attention in the first five seconds.

ii. Early registration of the brand name.

iii. There must be an evidence of the fulfillment of the promised benefits.

2. TV programmes where advertising can be carried out:

Programme sponsorship, network shows, TV shows/programmes, sports announcement, outside show promoters, syndication

3. Approach to Broadcast Commercial: Monologue (one single voice), Humorous, Dialogue, Dramatization and Musical.

4. Types of TV commercials:

Product as a hero, product demonstration, problem-solution, slice of life, celebrity/testimonial, spokesperson presenter, endorsement, opportunistic style, people like me, storyline style, fantasy and teaser:

\subsection{Challenges of Television Advertising in Nigeria}

Some challenges encountered in the use of television advertising are as follows:

1. Television advertising is far from being flexible; there is absolute lack of control by the advertiser ie the broadcaster and audience control the television.

2. Lack of selectivity: television adverts covers the public(mass). It is programmed to reach a general audience, in which case, selectivity of audience becomes difficult.

3. Fragmented audience due to programme content's ability to select its audience.

4. The escalating cost of television advertising makes the medium expensive for advertising.

5. Television is very expensive to purchase in Nigeria therefore, there is a limited reach to customers.

\subsection{Consumption and Consumer Behaviour}

Consumption is the act of buying and utilizing a product or service ultimately. Consumption can be done by an individual, business or government. This means, consumption is the ultimate use of a product. Anyawuocha,(2005) defined consumption as the use of consumer's resource to satisfy his wants. The level of an individual's consumption is dependent on his level of income, accumulated income and all the amount of money which can be borrowed to supplement his income. Anyawuocha (2005) Avery (2009) defined a consumer as a person who actually uses the product or service available in the community. 
To Pride and Farrel (1980) as quoted by Ekpendu (2008) consumer behaviour is the decision process and act of people involved in buying and using products. According to Anyanwu (2005), it is the process whereby individuals decide whether, what, when, where, how and from whom to purchase goods and services. Busch and Houston, (1985), Assael (1985), Obasi (2002), Inyanga(1998), Onah et al. (2004), Perner (2007) and Ekeke (2008) have all given explanations on the concept of consumer behaviour. In all, the basic generalization of consumer behaviour according to Inyanya (1998) is that it deals with behaviour of individuals in the market place.

Agu and Ogbuji (2008), while quoting Anyanwu (2005) observed that there are internal and external forces at work that cause the individual to want certain products, prefer specific brands and stores over others. The internal factors are consumer needs, motives, perception, attitude and learning. The external determinants include; family, social, \& cultural influences, business, economic factors.

The buying decision process for the ultimate consumer has been captured by many scholars such as Kotler and Keller (2007). The key steps include: problem recognition, information search, evaluation of alternatives, purchase decision and post- purchase behaviour.

The quality of efforts put in by the buyer, especially at the information search stage will influence the outcome of the post-purchase experience. This is because the buyer will make efforts to avoid vendors or sellers that have higher rates of service failure (Agu 2015; Okpara 2012, Agbonito et al. (2007).

Kotler(1986) Obasi(2002) Ibekwe (2008) reported the model by Howard and Sheet (1969) developed as a framework that is widely applied to service consumer purchase decisions. The figure below shows it.

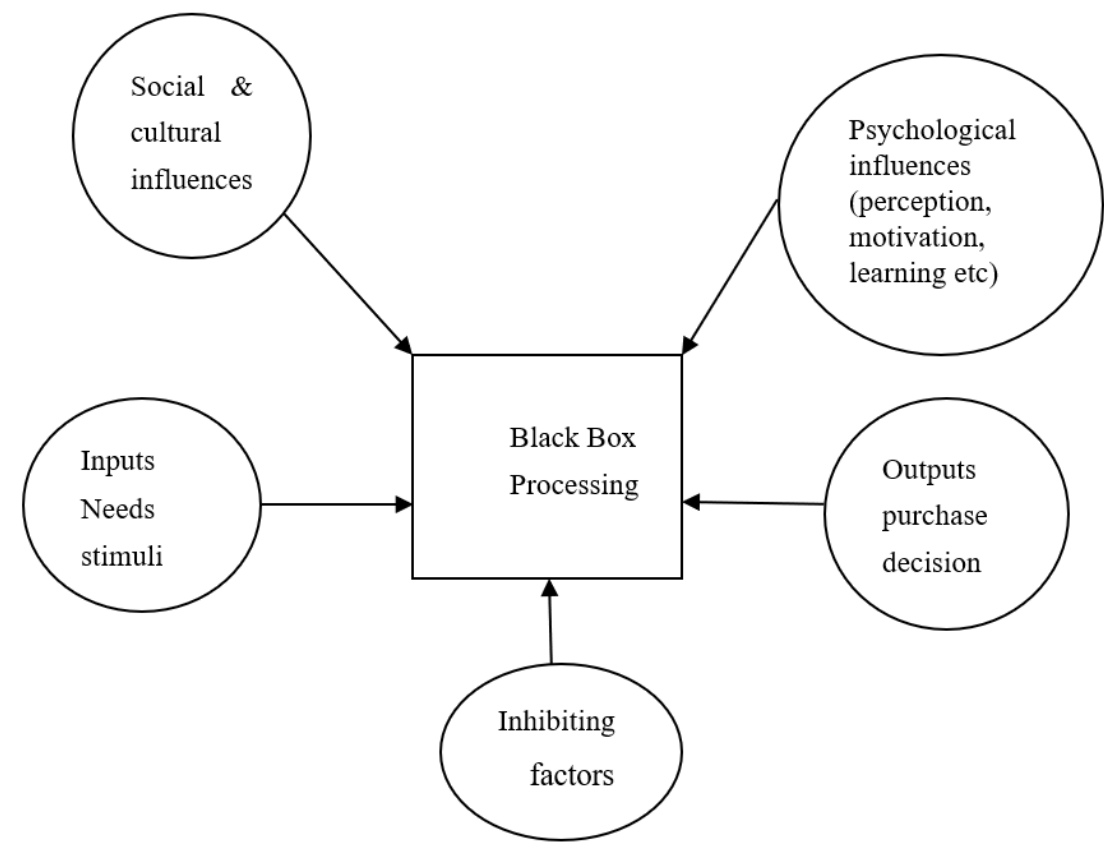

Figure 1. Model of consumer Behaviour Based on Howard and Sheth (1969)

Source: Howard and Sheth (1969) quoted by Ibekwe, F. C. (2008) "Service consumer behaviour" in contemporary Book on services Marketing. Owerri, Avan Global Press.

The model shows that a consumer decision to buy or not to buy a particular product takes place from the "Black Box", which possesses the major determinants of consumer behaviour such as social/ cultural influences, psychological influences etc. The inputs (needs, stimuli, information etc) and a number of inhibiting factors that tend to prevent the buyer from making positive move towards the purchase of the product are processed in the black box before the output which is the final decision to purchase. Based on these, the following null hypotheses were formulated:

\section{$\mathrm{HO}_{1:}$ Television advertising has not improved the patronage of indomie noodles.}

$\mathrm{HO}_{2}:$ Television advertising has not increased consumers preference for indomie noodles.

$\mathrm{HO}_{3}:$ Television advertising has no significant impact on consumers repeat purchase behaviour towards indomie noodles. 


\section{Theoretical Framework}

The AIDA theory and the Hierarchy of effect model guided this study. The AIDA theory is an acronym used in marketing which connotes attention, interest, desire and action. The AIDA theory was developed by St. Elmo Lewis in the late 1800s. This theory represents the stages marketers must take a customer through in an advertising process. The theory depicts the buyer as passing through attention phase down to the action (purchase) phase.

Advertising must first get the customers attention and even arouse interest the company's product or service (George \& Michael 2003). Strong level of interest should create desire to own or use the product. The action stage in this theory involves getting up the customers to make a purchase commitment.

This theory is related to this study because advertising must first, draw attention, then arouse interest before a desire is being created, to go for the product (action). Hereby, television advertising follows this procedure to promote and increase sales.

\subsection{The Hierarchy of Effect Model}

This model is used for determining advertising effect. This hierarchy is seen as a movement from the black box (where the buyer has no knowledge of what is in the box) to an open box (where the buyer knows the content of the box). When a producer manufactures a product item, he and the employees know about it. According to Anyanwu (2006), a customer who is totally unaware of the product goes through the following steps before a purchase is made.

a. Brand ignorance: Here, the potential buyer is ignorant and unaware about the existence of a product.

b. Awareness: The customer is unaware about a product (brand) and so, the task is to build brand awareness perhaps brand/name recognition with simple messages repeating the product till consumers are aware of the brand.

c. Knowledge: The target audience might have product awareness but unknown to them is the fact of what the product could do much more. Hence, this stage involves creating brand knowledge about the product. This is where the comprehension of the brand signs and what it depicts.

d. Liking: The customer develops a favourable attitude towards the product. If on the other hand, the audience do not like the product, the hierarchy comes to an abrupt end.

e. Preference: The target audience might like the product but prefers others to it. In this case, the communicator must try to build consumer preference by promoting quality value performance and other unique selling prepositions. (USP)

f. Conviction: The consumer believes in the product and being convinced that the product could meet its need with his desired satisfaction.

g. Purchases: Finally, some target consumers might have conviction but lack the purchase ability (power), they might wait later or for more information on buying. This is the final lap of the hierarchy of effect.

\subsection{Empirical Reviews}

Queen (2013), conducted a study on the Impact of Advertisement on Noodles Consumption. The purpose of the study was to measure the extent to which advertisement influences the behaviour of consumers of Indomie noodles. The sample size for the study was 75. A survey research was adopted for the study. A structured questionnaire was used for data collection. Three research questions were made for the study. The data collected was analyzed using chi-square. The study found that advertising has in no small measure helped to improve consumer preference for the product to other noodles. This study is related to this present study because the researcher adopted a survey research design with emphasis on advertising which the present study is carrying out, thereby serving as a guide to the present study.

Joshua (2011), conducted a study on the influence of television advertising on consumption of indomie noodles. A case study on the female staff tertiary institutions. The scope covers Taraba State. The purpose of the study was to determine the extent to which television advertising influences the consumption of Indomie noodles. The population of the study consists of 565. The study adopted a survey research design and a structured questionnaire was used for data collection. The study consisted of four research questions. The reliability coefficient of the instrument was 0.86 using Cronbach Alpha method. Three experts validated the instrument. Data collected was analyzed using mean statistic, standard deviation and t-test was used to test the hypotheses at 0.05 level of significance. The individual mean was computed using the Statistical Package for Social Sciences(SPSS). The study found that message on television advertising influence consumption of indomie noodles among the female 
staff of tertiary institutions in Taraba State. Joshua (2011) is related to this present study because the researcher adopted a survey research design and the emphasis is on television advertising, which this present study is carrying out a research on, therefore it will serve as a guide to this study.

Ibrahim (2009), conducted a study on the influence of television advertising on the consumers of alcoholic product in Taraba State. The major purpose of the study was to determine the influence of television advertising on consumers of alcoholic product in Taraba State of Nigeria. A survey research design was adopted for the study. A total of 1920 consumers of alcoholic product were randomly sampled out of a population of 38379 . A structured questionnaire was used for data collection. The reliability of 0.89 was determined. Three experts validated the instrument. Five research questions and five null hypothesis tested at 0.05 level of significance guided the study. Frequency, mean was used to answer the five research questions, while z-test statistic was employed to test for the null hypothesis. Ibrahim (2009) study found that television advertising influenced consumers of alcoholic product to a great extent. It was recommended that advertisers of alcoholic product should improve on their advertisement for greater impact and that deceptive advertising of alcoholic product should be discouraged. This study is related to this present study because the researcher adopted survey research design, and the emphasis is on television advertising, which present study is carrying out research on, therefore it will serve as a guide to this study. This study dealt with influence of television advertising on consumers of alcoholic product but the present study focuses on impact of television advertising on noodles consumption.

Kanu (2006) conducted a study on the influence of print advertising on purchase of women apparel by female lecturers in tertiary institutions in Imo state. The purpose of the study was to determine the influence of print advertising on purchase of women's apparel by female staff in some tertiary institutions in Imo state. The researcher had 188 lecturers as his sample out of the population of 2060. The study utilized a survey research design. A structured questionnaire was used for data collection. The reliability coefficient of instrument was 0.87 using Cronbach Alpha method in determining the internal consistency of the instrument reliability. Three experts validated the instrument. Five research questions and five null hypotheses were tested at 0.05 level of significance. The data collected was analyzed using the mean and standard deviation on 5-linkert scale, while student $t$-test was used to test null hypotheses. The study found out that print advertising influences purchase of woman apparel by female staff in tertiary institutions in Imo state using credible media while maintaining the quality of advertising product. The study recommended that the most effective media to female lecturers are newspapers and magazines and the study would want the Federal Government to ensure that advertisers are not unfair and deceptive in carrying out advertisement.

This study is related to the present study because both studies focus on advertising on products which is aimed at promoting consumption of a product. The study also adopted a survey research design which the present study has adopted, thereby serving as a guide to the present study while Kanu (2006) focused on influence of print advertising on purchase of women apparel, the present study focuses on impact of television advertising on consumption of noodles.

Chiwuike-Uba (2008) conducted a study on the influence of advertising on consumption of consumer goods. The purpose of the study was to determine the kind of effect advertising has on the consumption of consumer goods by government paid workers residing in Enugu state. The population used was 362 civil servants. The study adopted a survey research design. A structured questionnaire was used for data collection. The reliability coefficient of 0.86 using Cronbach alpha method was determined. Three experts validated the instruments. Four research questions and two null hypotheses were tested at 0.05 level of significance. The data collected from the subject was analyzed using mean and percentages while t-test was used to test the null hypotheses.

The study found that advertising influences consumption of food by the civil servants in Enugu state. The study recommended that the advertisers should use radio and television as a media for advertising.

The study is related to the present study because both studies adopted a survey research design to execute the studies. Therefore, the methodology adopted by the study will serve as a guide for the execution of the present study. Though Chiwuike-Uba (2008) study dealt with influence of advertising on consumption of consumer goods using different media, this present study focuses on impact of television advertising on noodles consumption.

\section{Research Methodology}

The study covered undergraduate students in Abia State University, Uturu. The subject scope of the research is domiciled on promotion and consumer behaviour. Both primary and secondary data were employed. Being a survey, structured questionnaire was on select students of the faculty of Business Administration. The instrument was structure in the likert format and subjected to a reliability test using the cronbach's al[ha which yielded an acceptable correlation of 0.87 . Study population was 18940 as at June 2018. Using the Taro Yeman, 392 sample 
size was determined. This was divided by 2 to arrive at 196 valid size for the study. The non-probability (convenience option) sampling technique was adopted. Collected data were analyzed with descriptive and inferential statistics. Stated hypotheses were tested using SPSS (version 20) one-sample t-test.

\subsection{Decision Rule}

The three null hypotheses will be tested using t-test statistics 0.05 level of probability. To test the null hypotheses, the researcher will restate the null hypotheses and the student's t-test will be used to determine the degree of difference in responses of the respondents in each of the null hypotheses. Where the $t$-calculated is more than ttabulated value, the null hypotheses will be rejected otherwise it will be accepted.

4.2 Data Presentation and Analysis

Table 4.1 Distribution and Retrieval of Instrument

\begin{tabular}{lllll}
\hline $\begin{array}{l}\text { No of copies } \\
\text { Distributed }\end{array}$ & $\begin{array}{l}\text { No of copies retrieved } \\
\& \text { used }\end{array}$ & $\begin{array}{l}\text { Difference } \\
\text { (copies lost) }\end{array}$ & $\begin{array}{l}\text { Percentage of lost } \\
\text { copies }\end{array}$ & $\begin{array}{l}\text { Percentage of retrieved } \\
\text { and used copies }\end{array}$ \\
\hline 196 & 180 & 16 & $8.00 \%$ & $92.00 \%$ \\
\hline
\end{tabular}

Source: Field survey, 2018.

Table 4.1 shows that a total of 196 copies of the questionnaire were distributed to respondents, a total of 180 (92\%) copies were retrieved and used. However, a total of 16 copies of the questionnaire were lost. This represents about $8 \%$ of the distributed questionnaire. This implies the analysis is based on the 180 copies that were retrieved and found useful for the purpose of the study.

Table 4.2 Gender of respondents

Source: Field Survey, 2018.

\begin{tabular}{llll}
\hline No & Options & Frequency & Percentage \\
\hline 1 & Male & 50 & $28.00 \%$ \\
& Female & 130 & $72.00 \%$ \\
& Total & 180 & 100 \\
\hline
\end{tabular}

The table above shows that $50(28 \%)$ are males and $130(72 \%)$ are females, making the female folks more than the male.

Table 4.3 Marital Status

Source: Field Survey, 2018.

\begin{tabular}{llll}
\hline S/N & Options & Frequency & Percentage \\
\hline 2 & Single & 138 & $77.00 \%$ \\
& Married & 40 & $22.00 \%$ \\
& Divorced & 2 & $11.00 \%$ \\
& Total & 180 & 100 \\
\hline
\end{tabular}

The table above indicates that $138(77 \%), 40(22 \%), 2(11 \%)$ of the respondents are single, married and divorced respectively.

Table 4.4 Distribution of respondents according to age

Source: Field Survey, 2018

\begin{tabular}{llll}
\hline S/N & Options & Frequency & Percentage \\
\hline 3 & $17-24$ & 70 & $38 \%$ \\
& $25-29$ & 100 & $56 \%$ \\
& $30-34$ & 5 & $3 \%$ \\
& $35-39$ & 5 & $3 \%$ \\
& Total & 180 & 100 \\
\hline
\end{tabular}


Table 4.4 shows the distribution of the respondents age. Respondents within the age of 17-24 are 70(38\%), 25-29 are $100(56 \%), 30-34$ are $5(3 \%)$ and $35-39$ are $5(3 \%)$.

Table 4.5 Distribution of respondents according to Educational Qualification

Source; Field Survey, 2018

\begin{tabular}{llll}
\hline S/N & Options & Frequency & Percentage \\
\hline 4 & O'Level & 75 & $43 \%$ \\
& OND & 30 & $16 \%$ \\
& HND & 45 & $25 \%$ \\
& B.Sc & 30 & $16 \%$ \\
& Total & 180 & 100 \\
\hline
\end{tabular}

The table above shows that $75(43 \%), 30(16 \%), 45(25 \%)$ and 30(16\%) of the respondents are O'level, OND, HND and B.Sc respectively.

Table 4.6 Responses showing the extent television advertising influences consumers' patronage of indomie noodles

\begin{tabular}{|c|c|c|c|c|}
\hline & Questions & Options & Frequency & Percentage \\
\hline \multirow[t]{7}{*}{5} & $\begin{array}{l}\text { Television advertising has influence on my patronage of } \\
\text { Indomie noodles }\end{array}$ & $\begin{array}{l}\text { Strongly } \\
\text { agree }\end{array}$ & 110 & $61 \%$ \\
\hline & & Agree & 60 & $33 \%$ \\
\hline & & Undecided & 10 & $6 \%$ \\
\hline & & Disagree & & \\
\hline & & & - & - \\
\hline & & $\begin{array}{l}\text { Strongly } \\
\text { disagree }\end{array}$ & - & - \\
\hline & Total & & 180 & $100 \%$ \\
\hline \multirow[t]{8}{*}{6} & $\begin{array}{l}\text { Television advertising influence my opinion on consumption of } \\
\text { Indomie noodles }\end{array}$ & $\begin{array}{l}\text { Strongly } \\
\text { agree }\end{array}$ & 130 & $72 \%$ \\
\hline & & Agree & 40 & $22 \%$ \\
\hline & & Undecided & 4 & \\
\hline & & & & $2 \%$ \\
\hline & & Disagree & 5 & $3 \%$ \\
\hline & & $\begin{array}{l}\text { Strongly } \\
\text { disagree }\end{array}$ & 1 & $1 \%$ \\
\hline & Total & & 180 & 100 \\
\hline & $\begin{array}{l}\text { The extent at which consumers are influenced by television } \\
\text { advertising on indomie noodle is high }\end{array}$ & $\begin{array}{l}\text { Strongly } \\
\text { agree }\end{array}$ & 135 & $76 \%$ \\
\hline \multirow[t]{5}{*}{7} & & Agree & 43 & $23 \%$ \\
\hline & & Undecided & 2 & $1 \%$ \\
\hline & & Disagree & - & - \\
\hline & & $\begin{array}{l}\text { Strongly } \\
\text { disagree }\end{array}$ & - & - \\
\hline & Total & & 180 & $100 \%$ \\
\hline
\end{tabular}

Source: Field Survey, 2018

Table 4.6 above, shows the extent at which television advertising influence consumers patronage on Indomie noodles which is very high. This is seen in the responses of the respondents, where $61 \%$ of the respondents strongly agreed that television advertising has influence on the patronage of Indomie noodles, $72 \%$ also strongly agreed that television advertising influence the opinion and consumption of Indomie noodles and $76 \%$ strongly agreed 
that the extent at which consumers are influenced by television advertising on Indomie noodles is very high in questions 5,6 \&7 respectively.

Table 4.7 Responses depicting how television advertising improve consumers preference of Indomie noodles.

\begin{tabular}{|c|c|c|c|c|}
\hline $\mathrm{S} / \mathrm{N}$ & Question & Options & Frequency & Percentage \\
\hline \multirow[t]{6}{*}{8} & $\begin{array}{l}\text { Television advertising has increase my brand preference } \\
\text { positively }\end{array}$ & $\begin{array}{l}\text { Strongly } \\
\text { agree }\end{array}$ & 120 & $66 \%$ \\
\hline & & Agree & 30 & $16 \%$ \\
\hline & & Undecided & 5 & $3 \%$ \\
\hline & & Disagree & 16 & $8 \%$ \\
\hline & & $\begin{array}{l}\text { Strongly } \\
\text { disagree }\end{array}$ & 9 & $5 \%$ \\
\hline & Total & & 180 & 100 \\
\hline \multirow[t]{6}{*}{9} & $\begin{array}{l}\text { The high purchase and consumption of Indomie noodles is a } \\
\text { resultant effect of television advertising }\end{array}$ & $\begin{array}{l}\text { Strongly } \\
\text { agree }\end{array}$ & 115 & $64 \%$ \\
\hline & & Agree & 45 & $25 \%$ \\
\hline & & Undecided & 13 & $7 \%$ \\
\hline & & Disagree & 7 & $4 \%$ \\
\hline & & $\begin{array}{l}\text { Strongly } \\
\text { disagree }\end{array}$ & - & - \\
\hline & Total & & 180 & 100 \\
\hline \multirow[t]{6}{*}{10} & $\begin{array}{l}\text { Catchy television advertising message influence consumers } \\
\text { preference of Indomie noodles }\end{array}$ & $\begin{array}{l}\text { Strongly } \\
\text { agree }\end{array}$ & 95 & $53 \%$ \\
\hline & & Agree & 70 & $38 \%$ \\
\hline & & Undecided & 5 & $3 \%$ \\
\hline & & Disagree & 9 & $5 \%$ \\
\hline & & $\begin{array}{l}\text { Strongly } \\
\text { disagree }\end{array}$ & 1 & $1 \%$ \\
\hline & Total & & 180 & 100 \\
\hline
\end{tabular}

Source: Field Survey, 2018

From Question 8, 120(66\%) respondents strongly agree that television advertising increase brand preference, $30(16 \%)$ agreed, 5(3\%) had not decided, $16(8 \%)$ disagreed and 9(5\%) strongly agreed. From Question 9, 115(64\%) respondents strongly agreed, 45(25\%) agreed, 13(7\%) had not decided, 7(4\%) disagreed and none strongly disagreed. In question 10, 95(53\%) respondents strongly agreed, 70(38\%) agreed, 5(3\%) had not decided, 9(5\%) disagreed and $1(1 \%)$ strongly disagreed.

Table 4.8 Responses depicting how television advertising create repeat purchase on consumption of Indomie noodles

\begin{tabular}{|c|c|c|c|c|}
\hline & Questions & Options & Frequency & Percentage \\
\hline 11 & $\begin{array}{l}\text { Decision on repeat purchase of Indomie noodle is an } \\
\text { influence of television advertising }\end{array}$ & $\begin{array}{l}\text { Strongly agree } \\
\text { Agree } \\
\text { Undecided } \\
\text { Disagree } \\
\text { Strongly } \\
\text { disagree } \\
\end{array}$ & $\begin{array}{l}100 \\
40 \\
40 \\
- \\
-\end{array}$ & $\begin{array}{l}56 \% \\
22 \% \\
22 \% \\
- \\
-\end{array}$ \\
\hline & Total & & 180 & 100 \\
\hline 12 & $\begin{array}{l}\text { Television advertising sustains brand purchase and } \\
\text { confidence }\end{array}$ & $\begin{array}{l}\text { Strongly agree } \\
\text { Agree } \\
\text { Undecided } \\
\text { Disagree }\end{array}$ & $\begin{array}{l}120 \\
40 \\
5 \\
10\end{array}$ & $\begin{array}{l}66 \% \\
22 \% \\
3 \% \\
6 \%\end{array}$ \\
\hline
\end{tabular}




\begin{tabular}{|c|c|c|c|c|}
\hline & & $\begin{array}{l}\text { Strongly } \\
\text { disagree }\end{array}$ & 5 & $3 \%$ \\
\hline & Total & & 180 & 100 \\
\hline & Consumers choice on purchase of Indomie is as a result of & Strongly agree & 110 & $61 \%$ \\
\hline 13 & television advertising message & Agree & 40 & $22 \%$ \\
\hline & Viewed & Undecided & - & - \\
\hline & & Disagree & 20 & $12 \%$ \\
\hline & & $\begin{array}{l}\text { Strongly } \\
\text { disagree }\end{array}$ & 10 & $5 \%$ \\
\hline & Total & & 180 & 100 \\
\hline
\end{tabular}

Source: Field Survey, 2018

From Question 11, 100(56\%) respondents strongly agreed that television advertising creates repeat purchase on Indomie consumption, $40(22 \%)$ agreed, $40(22 \%)$ had not decided, none disagreed nor strongly disagreed. Question $12,120(66 \%)$ respondents strongly agreed, $40(22 \%)$ agreed, $5(3 \%)$ had not decided, $10(6 \%)$ disagreed and 5(3\%) strongly disagreed. Question 13, 110(61\%) respondents strongly agreed, 40(22\%) agreed, none had not decided, $20(12 \%)$ disagreed and 10(5\%) strongly disagreed.

Table 4.9

Test of Hypothesis One

Ho: Television Advertising has not significantly improved consumers' patronage of indomie noodle.

To test this hypothesis, the data on question 5 were used and SPSS one-sample t-test applied.

Result

One-Sample Statistics

\begin{tabular}{|c|c|c|c|c|c|c|}
\hline & & \multirow[t]{3}{*}{ Statistic } & \multicolumn{4}{|c|}{ Bootstrap $^{a}$} \\
\hline & & & \multirow[t]{2}{*}{ Bias } & \multirow[t]{2}{*}{ Std. Error } & \multicolumn{2}{|c|}{$95 \%$ Confidence Interval } \\
\hline & & & & & Lower & Upper \\
\hline \multirow{4}{*}{ Patronage } & $\mathrm{N}$ & 180 & & & & \multirow{4}{*}{$\begin{array}{l}4.6389 \\
.65577\end{array}$} \\
\hline & Mean & 4.5556 & \multirow{3}{*}{$\begin{array}{l}-.0020 \\
-.00242\end{array}$} & \multirow{3}{*}{$\begin{array}{l}.0440 \\
.03030\end{array}$} & \multirow{3}{*}{$\begin{array}{l}4.4667 \\
.54068\end{array}$} & \\
\hline & Std. Deviation & .60002 & & & & \\
\hline & Std. Error Mean & .04472 & & & & \\
\hline
\end{tabular}

a. Unless otherwise noted, bootstrap results are based on 1000 bootstrap samples

Table 4.10

One-Sample Test

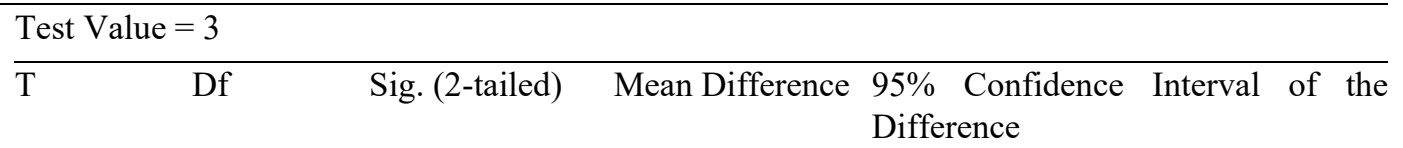

\begin{tabular}{|c|c|c|c|c|c|c|}
\hline & & & & & \multicolumn{2}{|c|}{ Difference } \\
\hline & & & & & Lower & Upper \\
\hline Patronage & 34.782 & 179 & .000 & 1.55556 & 1.4673 & 1.6438 \\
\hline
\end{tabular}

Table 4.11

Bootstrap for One-Sample Test

\begin{tabular}{|c|c|c|c|c|c|}
\hline \multirow[t]{3}{*}{ Mean Difference } & \multicolumn{5}{|c|}{ Bootstrap $^{a}$} \\
\hline & \multirow[t]{2}{*}{ Bias } & \multirow[t]{2}{*}{ Std. Error } & \multirow[t]{2}{*}{ Sig. (2-tailed) } & \multicolumn{2}{|c|}{ 95\% Confidence Interva } \\
\hline & & & & Lower & Upper \\
\hline 1.55556 & -.00203 & .04400 & .001 & 1.46667 & 1.63889 \\
\hline
\end{tabular}

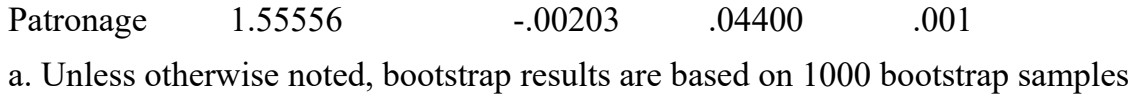




\subsection{Interpretation}

The one-sample statistics shows a mean value of 4.56 with lower and upper mean values of 4.47 and 4.64 respectively. This implies that an average respondent sampled strongly agreed that advertising impacts on patronage of indomie.

\subsubsection{Decision}

Given the value of t-test calculated (37.78), and P-value (Sig.2 tailed) of (.000) which are greater than t-critical (1.96) at degree of freedom (179) and alpha (.05), we therefore reject the null and accept the alternate hypothesis which implies that television Advertising has significantly improved consumers' patronage of indomie noodle.

\subsubsection{Test of Hypothesis Two}

Ho: Television Advertising has not significantly improved consumers' preference of indomie noodle.

To test this hypothesis, the data on question 8 were used and SPSS one-sample t-test applied.

\subsection{Results}

Table 4.12

\section{One-Sample Statistics}

\begin{tabular}{|c|c|c|c|c|c|c|}
\hline & & Statistic & Bootstra & & & \\
\hline & & & Bias & Std. Error & $95 \% \mathrm{Co}$ & e Interval \\
\hline & & & & & Lower & Upper \\
\hline & $\mathrm{N}$ & 180 & & & & \\
\hline Preference & Mean & 4.2944 & .0027 & .0925 & 4.1003 & 4.4722 \\
\hline Preference & Std. Deviation & 1.21304 & -.00916 & .08370 & 1.02732 & 1.36609 \\
\hline & Std. Error Mean & .09042 & & & & \\
\hline
\end{tabular}

a. Unless otherwise noted, bootstrap results are based on 1000 bootstrap samples

Table 4.13

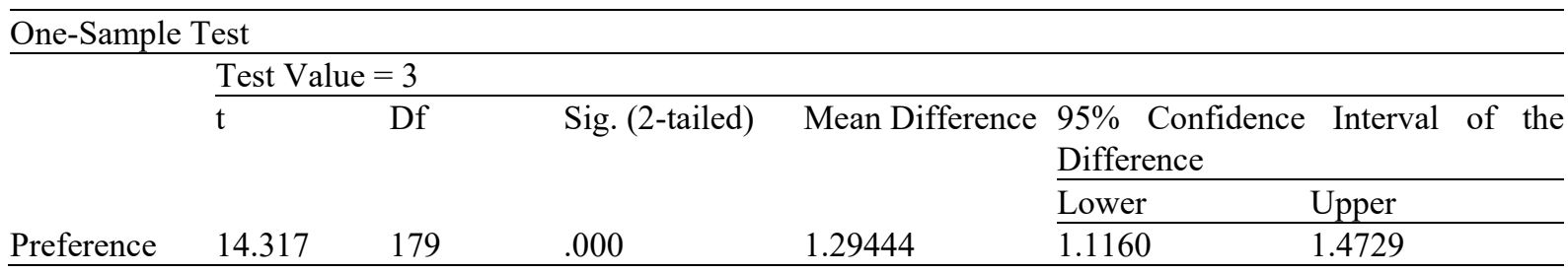

Table 4.14

Bootstrap for One-Sample Test

Mean Difference Bootstrap ${ }^{\mathrm{a}}$

\begin{tabular}{lllll}
\hline Bias & Std. Error & Sig. (2-tailed) & \multicolumn{2}{l}{$95 \%$ Confidence Interval } \\
\cline { 3 - 5 } & & & Lower & Upper \\
\cline { 3 - 5 } .00270 & .09253 & .001 & 1.10028 & 1.47222 \\
\hline
\end{tabular}

a. Unless otherwise noted, bootstrap results are based on 1000 bootstrap samples

\subsubsection{Interpretation}

The one-sample statistics shows a mean value of 4.29 with lower and upper mean values of 4.10 and 4.47 respectively. This implies that an average respondent sampled agreed that advertising impacts on preference of indomie.

\subsubsection{Decision}

Given the value of t-test calculated (14.32), and P-value (Sig.2 tailed) of (.000) which are greater than t-critical (1.96) at degree of freedom (179) and alpha (.05), we therefore reject the null and accept the alternate hypothesis which implies that television Advertising has significantly improved consumers' preference of indomie noodle. 


\subsubsection{Test of Hypothesis Three}

Ho: Television Advertising has not significantly improved consumers' repeat purchase of indomie noodle.

To test this hypothesis, the data on question 12 were used and SPSS one-sample t-test applied.

4.5 Result

Table 4.15

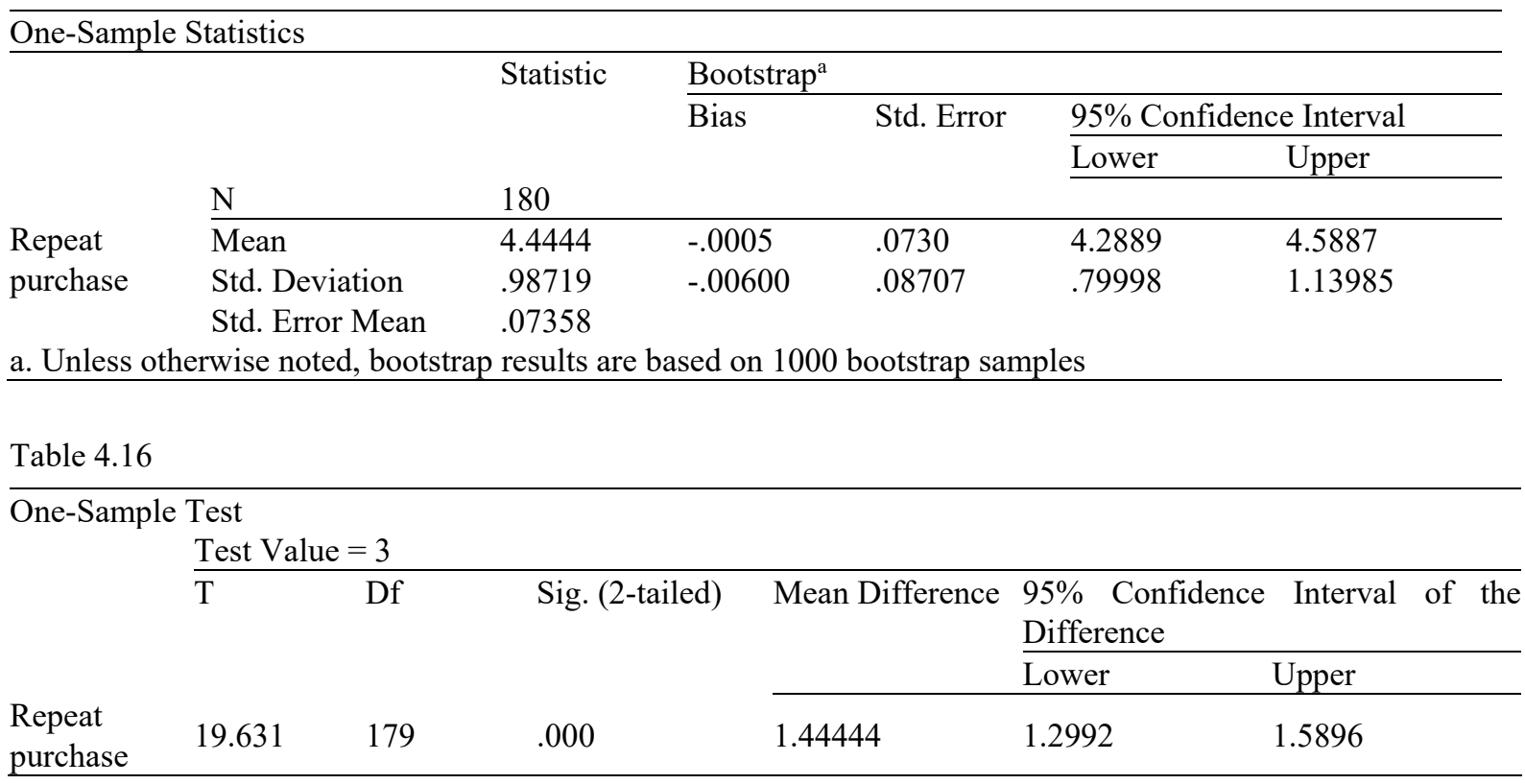

Table 4.17

\begin{tabular}{|c|c|c|c|c|c|c|}
\hline \multicolumn{7}{|c|}{ Bootstrap for One-Sample Test } \\
\hline & \multirow{3}{*}{ Mean Difference } & \multicolumn{5}{|c|}{ Bootstrap $^{a}$} \\
\hline & & \multirow[t]{2}{*}{ Bias } & \multirow[t]{2}{*}{ Std. Error } & \multirow[t]{2}{*}{ Sig. (2-tailed) } & \multicolumn{2}{|c|}{$95 \%$ Confidence Interva } \\
\hline & & & & & Lower & Upper \\
\hline $\begin{array}{l}\text { Repeat } \\
\text { purchase }\end{array}$ & 1.44444 & -.00047 & .07304 & .001 & 1.28889 & 1.58875 \\
\hline
\end{tabular}

\subsubsection{Interpretation}

The one-sample statistics shows a mean value of 4.44 with lower and upper mean values of 4.28 and 4.59 respectively. This implies that an average respondent sampled agreed that advertising impacts on repeat purchase of indomie.

\subsubsection{Decision}

Given the value of t-test calculated (19.63), and P-value (Sig.2 tailed) of (.000) which are greater than t-critical (1.96) at degree of freedom (179) and alpha (.05), we therefore reject the null and accept the alternate hypothesis which implies that television Advertising has significantly improved consumers' repeatpurchase of indomie noodle.

\subsection{Summary of Findings}

Based on the analyzed data, the following key findings were made in this study;

- It was discovered through this study that television advertising has significant influence on students' patronage of Indomie noodles.

- It was equally discovered through the study that television advertising has significant impact on students' preference of Indomie noodles.

- That television advertising has significantly improved students' repeat purchase of Indomie noodles. 


\section{Conclusion}

It is obvious that this study has revealed television advertising as a primary tool in the marketing decision variables of a firm and its effective in the marketing of Indomie noodles. Based on the findings of the study, it could be concluded that consumers' patronage, preference and repeat purchase are positive determinants of television advertising. Leveraging these key attributes would enhance competitiveness of Indomie noodles.

\section{Recommendations}

The following are some of the recommendations from this study;

- Television advertising should be seen as an investment into the future of products and not to be evaluated by its immediate returns.

- It is also advisable to identify a target market before televising, so to minimize cost for an increase in returns.

- In order to reduce the rate of advertising clutter, the government should give network incentives to reward marketers whose advertisement people love and penalize those who produce advertisement that viewers hate.

- Advertising messages should be clear, credible and precise so that the target market will not give different meanings to it.

- Deceptive television advertising meant that mislead consumers of noodles should be discouraged.

\section{References}

Agu, G. A. (2015) Customer-complaint Behaviour in the service industry; A study of the customers of the organised Road Transport Firms In Imo State. A ph.D Thesis, Abia State University, Nigeria.

Aham, A. (1998). Marketing in action. Owerri; Klet-ken publisher.

Aham, A. (2000). Dimension of Marketing. Owerri; Avan Global Publications.

Aham, A. (2003). Promotional strategy- A schematic Approach. Owerri; Avan Global publications.

Aham, A. (2013). Marketing Management and Strategy. Owerri: Avan Global Publications.

Anyanwuocha, R. A. I (2005). Fundamentals of Economics for Senior Secondary Schools. Abuja; Africa First Publishers Ltd.

Avery, J. (2009). Student-run advertising agency. A show case for student work. Retrieved $20^{\text {th }}$ April 2012.

Awa, I., \& Kalu, I. N. (2016).Marketing Communications: An integrated Approach. Nationwide Printers and Publications.

Chinedu, N. O. (2013). Marketing Research Port-Harcourt: African Entrepreneurshipand Leadership Initiative (AELI).

Doughudje, C. (1993). Creativity in Advertising: Journal of Marketing Management, Enugu Nigeria, University of Nigeria.

Ezejelue, A. C., Ogwo, E. O., \& Nkamnebe, A. D. (2017). Basic Principles in Managing Research Projects.Aba: Afritowers Ltd.

Gotoh, N., \& Wada, S. (2005). The importance of peroxide value in accessing good quality and food. Safety Journal of the American Oil Chemists Society, 473-474. https://doi.org/10.1007151176806-1229

Inyanga, J. (1998). Nigerian Marketing System. The marketing mix Approach. Global press limited.

Kaiser, U., \& Song, M. (2009). Do media consumers really dislikeadvertising. An empirical assessment of the role of advertising in electronic media marketer. International journal of Industrial Organisation, 22(2). https://doi.org/10.1016/j.ijindorg.2008.09.003

Kotler, P., Armstrong, G., Saunders, J., \& Wong, U. (2006). Principles of Marketing, New Jersey: Prentice Hall Inc.

Nwaizigbo, I. C. (2004). Principles of Marketing. Enugu: New generation books.

Okpara, G. S. (2012). Contemporary Marketing: Topical and Tropicalised. Owerri: Avan Global Publications.

Okpara, G. S., \& Agu, G. A. (2016). IntermediateMarketing; Bridging the gap between foundational and special marketing thoughts. Owerri: Avan Global Publications.

Okpara, G. S., Anyanwu, A., \& Inyanga, J. I. (1999). Marketing Communication principles and practices; Portharcourt Educational Books and investment. 
Onah, J. O., \& Thomas, M. J. (2004). Marketing Management: Strategies and cases. Enugu. Institute for Development Studies.

Stephen, D. (2010). Measuring Situational triggers of television advertising for avoiding ads by fast-forwarding through commercials. Retrieved $21^{\text {st }}$ April 2012.

Wikipedia. (2018). Consumption. Retrieved July 20, 2018, from http://en.m.wikipedia.org/wikiconsumption

Wikipedia. (2018). Frequency of television advertising. Retrieved July 12, 2018, from http://em.Mwikipedia.org/wiki/effective frequency

William, F. A. (2006). Advertising. Irwin: McGraw Hill.

\section{Copyrights}

Copyright for this article is retained by the author(s), with first publication rights granted to the journal.

This is an open-access article distributed under the terms and conditions of the Creative Commons Attribution license (http://creativecommons.org/licenses/by/4.0/). 